\title{
Assuring the Antecedents of Pantheism and Metaphysical Speculation in Coleridge's Poetic Work
}

\author{
Aslam Yasir \\ Department of English Language and Literature, Kwangwoon University, Seoul, South Korea \\ Email address: \\ yasirkr86@gmail.com \\ To cite this article: \\ Aslam Yasir. Assuring the Antecedents of Pantheism and Metaphysical Speculation in Coleridge's Poetic Work. International Journal of \\ Architecture, Arts and Applications. Vol. 6, No. 3, 2020, pp. 34-38. doi: 10.11648/j.ijaaa.20200603.11
}

Received: February 12, 2020; Accepted: June 15, 2020; Published: July 7, 2020

\begin{abstract}
This article is about the poetic work of Coleridge's pantheism and metaphysical speculations. As he is one of the most influential poets of the romantic period in the field of English literature. He considered the wonderfully imaginative, psychological, metaphysical and pantheistic romantic poems with comparing other greatest poets by a recognized location. There are number of aspects in Coleridge's personality and also in his writings consists of philosophy, religion, metaphysical aspects, irony, imagination, metaphor, and pantheism. In this research article, the discussion is taken from his most impressive poems "The Ancient Mariner", "The Eolian Harp", "Religious Musings" and "This Lime-Tree Bower My Prison", which shows Coleridge's representation of of terms Patheism and metaphysical spaculations. Coleridge gave two philosophical declarations. These two declarations are related to his concept of "one Life". They are related to the different theories and symbolically different. The first declaration appears after Coleridge connotation with the breeze that has caressed the lute, the second declaration is about his previous experience where he had been little more than a passive lute being caresses by the breeze. Hence these two declarations come to know after a representation of imagination and after explaining of fancy in the period of Romantisicim.
\end{abstract}

Keywords: Pantheism, Metaphysical Speculation, Romanticism, Imaginations

\section{Introduction}

And Coleridge, too, has lately taken wing, But like a hawk, encumber'd with his hood, Explaining metaphysics to the nation,

I wish he would explain his Explanation. (Byron Don Juan)

Coleridge's life has demonstrated hard to report. As a developmental perspective, he used very difficult tasks. In the comparison of historic political and social change in Britain and Europe during the period of his life, his ambition to articulate a philosophy of unity had sometimes ended up with success and sometimes with failures [16].

The poetic period of Coleridge with his contemporaries Wordsworth in North Stowey was his great period. The Conversation poems, 'The Ancient Mariner' are his great work as compared to the collaborative Lyrical Ballads, and also 'Kubla Khan' and the first part of 'Christabel'. Coleridge wrote a poem that was 'The Eolian Harp', in the 'Conversation' poems in 1817 [12]. Coleridge wrote on the page that began 'The Eolian Harp', which shows his great work about pantheism and his use of metaphysical speculations:

"Let me be excused, if it should seem to others too mere a trifle to justify my noticing it but I have some claim to the thanks of no small number of the readers of poetry in having first introduced this species of short blank verse poems of which Southey, Lamb, Wordsworth, and others have since produced so many exquisite specimens. In Sibylline Leaves 'The Eolian Harp' was placed among 'Meditative Poems in Blank Verse' with poems we now call 'Conversation Poems'. George McLean Harper coined the term 'Conversation Poems' in 1928, borrowing the subtitle of 'The Nightingale. A Conversation Poem' and following the epigram from Horace to 'Reflections on Having Left a Place of Retirement': 'Sermoni propriora', 'more fitted to conversation or prose'. Harper described them as 'poems of friendship', since they were all written to a close friend, and included in the category 'The Eolian Harp' (Aug. 1795), 'Reflections of Having Left a Place of Retirement' (Oct. 
1796), 'This Lime-Tree Bower My Prison' (July 1797), 'Frost at Midnight' (Feb. 1798), 'The Nightingale' and 'Fears in Solitude' (both April 1798), 'Dejection: An Ode' (April 1802) and 'To William Wordsworth' (Jan. 1807)."

M. H Abrams in 1968 mentioned that Coleridge was a wonderful metaphysical poet and he called him the 'greater Romantic Lyric', a movement that started with his 'Conversation' poems, and Keats 'Ode to Nightingale', William Wordsworth's 'Tintern Abbey', 'Shelley's Stanzas written in Dejection', and it is more influenced by modern poems by Mathew Arnold, Walt Whitman, Wallace Stevens and W. H Auden [10].

\section{Discussion}

"The speaker begins with a description of the landscape; an aspect or change of aspect in the landscape evokes a varied but integral process of memory, thought, anticipation, and feeling which remains closely intervolved with the outer scene. In the course of this meditation, the lyric speaker achieves an insight, faces up to a tragic loss, comes to a moral decision, or resolves an emotional problem. Often the poem rounds upon itself to end where it began, at the outer scene, but with an altered mood and deepened understanding which is the result of the intervening meditation [9]."

Many of the poems of ST Coleridge like "The Ancient Mariner", "The Eolian Harp", "Religious Musings", "This Lime-Tree Bower My Prison" and many others reflect his concentration towards pantheism like symbols of sounds wind, snake, and bower that is used is his poems. The big planning of revolutionary history became the story of once redemption. In the 'science' which demonstrated nature as a God working to develop pantheism which gave way to the magic and showed it as God is looking after for man instead of ST Coleridge wrote a work of imagination [5]. Regrettably, it is not a point to follow Coleridge's concept of nature by his conversations with Wordsworth on the matter of imagination as his poem 'The Ancient Mariner' reflects this concept by using the concept of metaphysical speculations.

This poem is about the oneness of nature and man. Coleridge is known as the most philosophical and metaphysical poet of the romantic era. This poem proceeds with a long journey, which starts calmly, to the man being saved from the bird in the difficulty, and then retribution after the man killed the bird and then at the end man saved again after many difficulties.

The poem 'The Rime of the Ancient Mariner' is about punishment and crime. This concept has shown an image of the chase of Western humanistic ideas and beliefs. It is the contradiction of human-centered mind. The whole story of this poem is not complicated but the theme is very deep like punishing voice, praising virtue and harmonious unity. It is said that God created conflict between man's desire and duty when he created a man [7]. According to the Western literary practice and ethics, the concept of crime and punishment are explained in two ways one is a desire to the source of crime and the other is the punishment which is the caution of responsibility. Moreover, in this poem, the albatross is the symbol of the spirit of Christ. The killing of the albatross is equal to the rejection of God. At the same time, God gives freedom to man which is ultimately the reflection of crime and punishment. Also, the symbol of the appearance of the shining water snake represents the rebirth of the Holy Spirit. Shooting of albatrosses to the holy prayer for the water snake by the sailor symbolizes the tracking root from the starting point of sin to the sorrow and rebirth [8]. In the poem, 'The Eolian Harp', the opening lines represents the opening of the "Reflection on Having Left a Place of Retirement". The fait accompli at the time is the unity with nature, achieved by the medication of Sara, level of mind and nature is used is a symbolism [2]. As is narrated:

My pensive Sara! thy soft cheek reclined Thus on my arm, most soothing sweet it is

To sit beside our Cot, our Cot o'ergrown

With white-flower'd Jasmin, and the broad-leav'd Myrtle,

(Meet emblems they of Innocence and Love!)

And watch the clouds, that late were rich with light

Slow saddening round, and mark the star of eve

Serenely brilliant (such should Wisdom be)

Shine opposite! How exquisite the scents

Snatch'd from yon bean-field! and the world so hush'd!

The stilly murmur of the distant Sea

Tells us of silence.

('The Eolian Harp', ll. 1-12)

The poem goes forward to find the wanderings of the poet's mind, originated and informed by the interaction of 'The Eeolian Harp' and the wind which was bellowing very fast to give the poet more comfort. 'The Eeolian Harp' was a standard household pattern set up outside the house to sound in the response to the wind and also represents a symbol for an eighteenth century. This wind is a symbol of music for the poet.

As wild and various as the random gales

That swell and flutter on this subject Lute!

('The Eolian Harp', ll. 39-43)

By the interaction of the wind and harp, the first 'Phantasy' aggravated. They also represent the passion of the two lovers which they shared during the months of relationship with the hope that God is everywhere and God is with us [13]. One thing is noted that Romantic poets were not the full believer of religion. If they worship of God, it means it is their reality of the mind. The believed that the actual heaven was nothing but the freedom of heart. According to Coleridge, to find God is just like to find the truth of the world. Like his poems, he reflects nature as the beautiful creation of God [1].

How by the desultory breeze caressed,

Like some coy maid half yielding to her lover,

It pours forth such upbraiding, as must needs

Tempt to repeat the wrong! And now, its strings

Boldlier swept, the long sequacious notes

Over delicious surges sink and rise

('The Eolian Harp', ll. 14-9)

While moving further, this pantheistic speculation, which 
tells that God is everywhere in the universe and he has control over each and every tiny part of the universe that is shown in the last sixteen lines of the poem. These lines show a sudden evacuation to a basic, and many scholars have worried about a certain attitude because at the beginning of the poem 'The Eolian Harp', it seems a happy journey. In the later text of the poem, the lines 26-33, 'O! The one Life within us and abroad' represents that they upset the poet himself for the outstanding ending of the poem which represents the Pantheistic flows that the poet originally refused. With the pantheistic findings, Coleridge faced immense criticism. The ending lines of the poem clearly characterized the mind and personality of Sara. When he said 'Peace, and this Cot and thee

Heart-honored Maid" here Maid means Sara.

But thy more serious eye a mild reproof

Darts, $O$ beloved woman! nor such thoughts

Dim and unhallowed dost thou not reject,

And biddest me walk humbly with my God.

(The Eolian Harp', ll. 49-52)

Moreover, Coleridge feels unlucky to keep in relation with Sara and he concluded that Sara is responsible for the breakdown of their marriage, so, she could not fulfill the need of Coleridge's own. The imitative philosophical speculations of a combination of our knowledge between Sara's and Coleridge's marriage reflects a bad image in this poem [4]. This poem emphasizes what we think the poet would like to have called, the "governess "Sara not been there to criticized him. One of the most important thing while discussing the Coleridge's metaphysical speculation is his pervasive ambivalence towards the metaphysical speculation [4]. Coleridge rises the point renovated by the sunlight, but the very bower which had once been a prison becomes a witness of this translucence of God in his creation: 'Pale beneath the blaze Hung the transparent foliage' [14].

According to Coleridge point of view, nature is not an absurd object. By contrasting it he said that it is a masterpiece and in term of spirit it is a great creation of God. However, knowledge of nature and life are totally different. In the past, it is noted that the honesty of performance, Ideas and product all took place at once. But there is no deep activity in the center of it. Also, man is the leader of all the visible creation of God according to its own freedom and choice [11].

"The one Life within us and abroad,

Which meets all motion and becomes it soul."

The derivation away from the mind of poet and spirit in an act of sympathetic identification that has enabled the inward derivation of the sun. Coleridge's love for his friend Charles and divine love for naturalism which is everywhere in the world is just like as the sun exits over the natural world [9]. As Coleridge said in one of his notebooks that "Man knows God only by revelation from God", again remarked by him "as we see the sun by his own light". In Coleridge's poem 'This Lime-Tree Bower My Prison' is a reflection of the one life within us and abroad. He also considered in 'The Eolian Harp' a sense which he enlightens in Hebrew poetry: the concept of everything has itself a life for once own and they are all a compound of one life. In God, they live, move and have their being'. In line 26 of "The Eolian Harp", "O! The one life within us and abroad!" Coleridge's concern about one life seemed to be displayed as a truth model of huge experience. It also reflects the Post-Newtonian concept in 1816 when he adds this line to the poem. He has written to Southey in back 1802 that nature will be her extreme interest only to him, "we are all one life for those who think that everything has a life of its own." Poet used blackbird which symbolized death it means every living being have to face the reality of death. As in the following lines:

when the last rook

Beat its straight path along the dusky air

Homewards, I blest it! deeming its black wing

(Now a dim speck, now vanishing in light)

Had cross'd the mighty Orb's dilated glory

While thou stood'st gazing

('This Lime-Tree Bower My Prison', ll. 68-73)

In the poem 'This Lime-Tree Bower My Prison', the importance of the sunlit landscape does not go on its climax. In 1802 William Southey also recognized Coleridge as a poet of sense of unity and called him 'beyond all others imagination. He also considered a link between the 'One Life' and the imagination of the poet as this imaginative power controlled by God. In 'Religious Musing', when speaking 'The Elect' under another name:

Contemplant Spirits! ye that hover o'er

With untired gaze the immeasurable fount

Ebullient with creative Deity!

And ye of plastic power, that interfused

Roll through the grosser and material mass

In organizing surge! Holies of God!

(Religious Musings, ll. 402-7)

Metaphysical speculation is known by ST Coleridge as physically disabled and emotionally out of order [3]. 'This perpetual Struggle, this endless heart-wasting', Coleridge called his marriage to Sara was a misfortune, while writing to Danial Stauart in 1806.

'was at the bottom of all my resolution, procrastination, languor, and former detestable habit of poison taking this turned me away so long from political and moral disquisition, poetry, and all the flowers \& herbs that grow in the Light and Sunshine, to be meanwhile a Delver in the unwholesome quick-silver mines of abstruse Metaphysics' (CL II, 1178).

ST Coleridge always remained associated with the 'complex Metaphysics' which he came to related in opium taking [15]. He called himself that I am addicted to it because he gave me relaxation and he said that; "I am so habituated to Philosophizing". He told in December 1794 to Southey that "I cannot divest myself of it even when my own Wretchedness is the subject". Through the metaphysics aspects like the opium, he seems to be an initial release from the crucial demands of reality. And also like opium, it is to be noticed that it leads to destruction at the end. This surly is an attitude of "Dejection an Ode".

not to think of what I needs must feel, 
But to be still and patient, all I can

And haply by abstruse research to steal

From my own nature all the natural man -

This was my sole resource, my only plan

Till that which suits a part infects the whole,

And now is almost grown the habit of my soul.

('Dejection An Ode', ll. 87-93 [my emphasis])

By metaphysical speculations, Coleridge finds his own life

like John Milton's "Paradise Lost". He got the mental feelings through emotional attachment like in his poems there are ebbs and flows about the psychological condition about the reality of life and desires. The most important example from the work of ST Coleridge was his poem "The Eolian Harp". As the final lines of the poems reflect some metaphysical speculations:

In this poem is not inconsistent. two different metaphysical experiences have been found in this poem, one is imagination and the second is recording fancy, both carried philosophical speculation: the first said that the belief on God depends on the person's inner belief while other means that God alone and himself generates the man's realization. Coleridge rejects the second concept not only because it does not fit on the mind of Sarah but because it is false. But at the end of this Poem, he finds peace by repenting in front of God, and he said that "These shaping of the unregenrate mind;" it means that he is praising God that he could make his mind according to His thinking. Also in another, he said that; "A sinful and most miserable man, Wildered and dark, and gave me to possess" It means that he is telling God that he is not a perfect man, God (you) should mercy on him.

Well hast thou said and holily disprais'd

These shap the ings of the unregenerate mind;

Bubbles that glitter as they rise and break

On vain Philosophy's aye-babbling spring.

For never guiltless may I speak of him,

The Incomprehensible! save when with awe

I praise him and with faith that inly feels;

Who with his saving mercies healed me,

A sinful and most miserable Man,

Wildered and dark, and gave me to possess

Peace, and this Cot, and thee, heart-honoured Maid!

\section{Conclusion}

Coleridge used the term Pantheism to summarize the levels of responsibility in the human spirit and desire according to the human mind. In his poems "The Ancient Mariner", "The Eolian Harp", "Religious Musings", "This Lime-Tree Bower My Prison" and many others he just transfers the metaphysical features in an easy way with the help of idioms, metaphor, irony, pantheistic approach and imaginary towards the real world. He is called the one of the best poet of using metaphysical features in the romantic period. There are a number of aspects in the personality of Coleridge and in his writings philosophy, religion, metaphysical aspects, irony, imagination, metaphor and pantheism [6].
He used the term pantheism to show the importance of God to him as at the poem "The Eolian Harp" he repents himself and calls God for his help. He prays to God that makes his mind according to the thinking of God and have mercy on him. He has the spiritual journey of the whole generation from essential to tradition, rationalist, to philosophical idealism and religionist to pantheism. These qualities gives us some of his failures and some of his successes in his golden life [16]. He wrote the poem "The Rime of the Ancient Mariner". It showed his masterpiece of writing in which showed nature as God When he has made a comparison between the shining sun and the sea of diamonds.

In the works of Coleridge, which represents his metaphysical boundaries happened in the first chapter of 'Biographia'. Where he mentions the very crucial philosophical issue in John Milton's 'Paradise lost' of the falling angels.

Of providence, fore-knowledge, will, and fate,

Fix'd fate, free will, fore-knowledge absolute,

And found no end in wandering mazes lost

The lovely shapes and sounds intelligible

Of that eternal language, which thy God Utters.

('Frost at Midnight', ll. 58-61)

\section{References}

[1] C. F. (2006). "Coleridge's perception of nature and ecologicalawareness." Academic Journal of Zejiang, (6).

[2] Coleridge, S. T. (1984). "Biographia literaria, or, biographical sketches of my literary life and opinions (Vol. 7)." Princeton University Press.

[3] Dorenkamp, A. G. (1971). "Hope at Highgate: The Late Poetry of ST Coleridge". Barat Review, 6 .

[4] Emmet, D. M. (1952). "Coleridge on the Growth of the Mind." Bulletin of the John Rylands Library, 34 (2), 276-295.

[5] George Whalley, "Coleridge and Southey in Bristol, 1795," Review of English Studies, new ser., 1 (1950): p. 332n.

[6] Jones C. "Radical Sensibility: Literature and ideas in the 1790s." Routledge; 2016 Apr 6.

[7] Li, Y. Q. (1989). "Original sin in western contemporary literature, foreign literature and culture." Beijing: Xinhua Press.

[8] Lu, C. F. (2006). "Coleridge's perception of nature and ecological awareness." Academic Journal of Zejiang, (6).

[9] M. H Abram, (1968). The Norton Anthology of English Literature (Vol. II).

[10] M. H Abram, (1984). "The correspondent Breeze" Essays on English Romanticism.

[11] M. H Abrams, (1971). "Natural supernaturalism." New York: Norton.

[12] McGavran, J. H. (1996). "Defusing the Discharged Soldier: Wordsworth, Coleridge, and Homosexual Panic." Papers on Language and Literature, 32 (2), 147. 
[13] Richard Haven. (1969). Patterns of consciousness: "An essay on Coleridge." Univ of Massachusetts Press.

[14] S. T Coleridge, Ed. Earl Leslie Griggs "The Collected Letters of Samuel Taylor Coleridge, ed. Earl Leslie Griggs, 6 vols." (Oxford University Press, 1956-71).
[15] Warren, R. P. (1946). "A Poem of Pure Imagination (Reconsiderations VI)." The Kenyon Review, 8 (3), 391-427.

[16] Wordsworth, J. (1985). "The Infinite I AM: Coleridge and the Ascent of Being." The Wordsworth Circle, 16 (2), 74-84. 